\title{
Bilateral database on the characteristics of US and Soviet research reactors
}

FY-08 Deliverable under DHS IAA\# HSHQDC-08-X-00202 International Collaborations and Foreign Materials (WBS 1.1.2.1) Deliverable \# LLNL.08.005

Michael J. Kristo, Ph.D.,

Lawrence Livermore National Laboratory

September 2009 


\section{Disclaimer}

This document was prepared as an account of work sponsored by an agency of the United States government. Neither the United States government nor Lawrence Livermore National Security, LLC, nor any of their employees makes any warranty, expressed or implied, or assumes any legal liability or responsibility for the accuracy, completeness, or usefulness of any information, apparatus, product, or process disclosed, or represents that its use would not infringe privately owned rights. Reference herein to any specific commercial product, process, or service by trade name, trademark, manufacturer, or otherwise does not necessarily constitute or imply its endorsement, recommendation, or favoring by the United States government or Lawrence Livermore National Security, LLC. The views and opinions of authors expressed herein do not necessarily state or reflect those of the United States government or Lawrence Livermore National Security, LLC, and shall not be used for advertising or product endorsement purposes.

\section{Auspices Statement}

This work performed under the auspices of the U.S. Department of Energy by Lawrence Livermore National Laboratory under Contract DE-AC52-07NA27344. 


\section{Tasking}

LLNL will deliver to DHS DNDO/NTNFC a report detailing the status of the bilateral database project and a project plan for the successful test loading of the database. 


\section{Status Summary}

Our collaboration with the Institute of Technical Physics (VNIITF) in Snezhinsk, Russia, on "Development of the plan of the creation and information content of the joint database on the characteristics of USA and USSR research reactors" has been delayed significantly, mostly due to delays in VNIITF's obtaining approval from RosAtom for the project. We recently received word that VNIITF has received all approvals necessary to work on this project and that the Project Proposal has been sent to the ISTC. Unfortunately, ISTC is legally bound to have a 40-day comment period prior to finalizing any contract. Therefore, we cannot fund the contract before expiration of our FY08 funding. We are currently formulating a proposal to reallocate FY09 funding to accommodate both years of this proposal (FY09 NTNFC funding has already been provided for the second year of the work). 


\section{Timeline}

The following timeline will help explain the course of activities over the lifetime of the FY08 IAA:

\begin{tabular}{|l|l|}
\hline $3 / 7 / 08$ & $\begin{array}{l}\text { Start date of the LLNL FY08 IAA, HSHQDC- } \\
08-00202\end{array}$ \\
\hline $4 / 30 / 08$ & Funds available at LLNL \\
\hline $7 / 17 / 08$ & Contract with Russian interpreter established \\
\hline $7 / 30 / 08$ & $\begin{array}{l}\text { Initial conference call with Nikolai Gorin } \\
\text { (VNITTF),Bill Dunlop (LLNL), Mike Kristo } \\
\text { (LLNL), Dave Chamberlain (ANL) }\end{array}$ \\
\hline $8 / 20 / 08-9 / 10 / 08$ & $\begin{array}{l}\text { Moratorium on communication with Russians } \\
\text { due to necessity of DHS review as a } \\
\text { consequence of Russian invasion of Georgia }\end{array}$ \\
\hline $9 / 12 / 08$ & Draft SOW sent to VNIITF for their review \\
\hline $10 / 1 / 08$ & $\begin{array}{l}\text { Price estimate received - too much for funding } \\
\text { in 1 year }\end{array}$ \\
\hline $11 / 11 / 08$ & Draft SOW structured as a 2-year proposal \\
\hline $12 / 3 / 08$ & $\begin{array}{l}\text { LLNL provides ISTC with a partner } \\
\text { commitment letter (starts the ISTC process) }\end{array}$ \\
\hline $1 / 15 / 09$ & $\begin{array}{l}\text { VNIITF provides SOW in ISTC format for } \\
\text { LLNL review. }\end{array}$ \\
\hline $7 / 2 / 09$ & RosAtom approves project \\
\hline $8 / 25 / 09$ & $\begin{array}{l}\text { VNIITF notified that project requires export } \\
\text { approval in addition to RosAtom approval }\end{array}$ \\
\hline $9 / 1 / 5 / 09$ & $\begin{array}{l}\text { Export approval received; ISTC receives } \\
\text { proposal from VNIITF }\end{array}$ \\
\hline
\end{tabular}




\section{Future Activities;}

LLNL will review the draft Project Plan upon receipt from ISTC. We must ensure that the agreedupon SOW was not modified during the RosAtom approval process, such that it no longer meets our requirements. In addition, our contracting officers will make sure that the ISTC Project Plan meets the requirements of our DOE-approved contracting process. Our Russian contracting group is used to this process, so it should not result in excessive delay.

Once the LLNL contracting documents are accepted by the ISTC, LLNL will transfer the first year's funding to the ISTC. The ISTC pays VNIITF as they accomplish their tasks and provide the necessary deliverables. As we receive the deliverables, we will forward these to the NTNFC.

We can release the second year's funding to the ISTC at any point. Ideally, we would like to release those funds after successful completion of the first year's activities. However, due to the lengthy delays in establishing the contract, we must also be cognizant of the expiration date of the FY09 funding. We will make this decision in consultation with the NTNFC.

At the conclusion of the first year's activities, it may be useful to hold a meeting in Russia to review progress and make further plans for the second year's work. Again, we will make this determination in consultation with the NTNFC. 


\section{Attachment:}

1. Preliminary Statement of Work in ISTC format. 


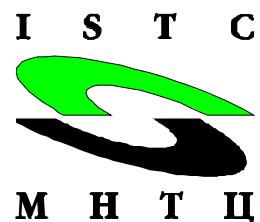

\section{PROJECT PROPOSAL}

\section{Summary Project Information}

\section{Project Title and Taxonomy}

Full title: Development of the plan of the creation and information content of the joint database on the characteristics of USA and USSR research reactors

Short title: Joint Database on Research Reactors

Technology area: FIR-FUE, FIR-MAT, FIR-NOT

Category of technology development: Applied studies

Key words: research reactors, identification, design of fuel elements

\section{Project Manager}

\begin{tabular}{|l|l|}
\hline Name: Gorin Nikolay Vladimirovich \\
\hline Title: Ph.D. & Position: Senior Scientist \\
\hline Street address: Vasilyev Street, 13 & \\
\hline City: Snezhinsk & Region: Chelyabinsk \\
\hline ZIP: 456770 & Country: Russia \\
\hline Tel.: $+7(35146)$ 53008 & Fax: +7(35146) 30125, 52070 \\
\hline E-mail: n.gorin@ @niitf.ru & \\
\hline
\end{tabular}

\section{Participating Institutions}

\subsection{Leading Institution}

\begin{tabular}{|l|l|}
\hline Short reference: RFNC VNIITF \\
\hline Full name: FSUE Academician Zababakhin Russian Federal Nuclear Center - All-Russian Scientific \\
\multicolumn{1}{|l|}{ Research Institute of Technical Physics } \\
\hline Street address: Vasilyev Street, 13 \\
\hline City: Snezhinsk & Region: Chelyabinsk \\
\hline ZIP: 456770 & Country: Russia \\
\hline Name of Signature Authority: Rykovanov Georgy Nikolayevich \\
\hline Title: Corresponding Member of RAS & Position: Director of RFNC VNIITF \\
\hline Tel.: (35146) 32625 & Fax: (35146) 32077 \\
\hline E-mail: g.n.rykovanov@,vniitf.ru \\
\hline Governmental Agency: Statecorporation Rosatom \\
\hline
\end{tabular}

\subsection{Other Participating Institutions}

None

\section{Foreign Collaborators/Partners}

\subsection{Collaborators}

None 


\subsection{Partners}

\begin{tabular}{|c|c|}
\hline \multicolumn{2}{|c|}{ Institution: $\quad$ Department of Energy, Lawrence Livermore National Laboratory } \\
\hline \multicolumn{2}{|l|}{ Street address: $\quad$ East Avenue } \\
\hline City: Livermore & Region/State: California \\
\hline ZIP: $\quad 94550$ & Country: USA \\
\hline \multicolumn{2}{|l|}{ Signature Authority: $\quad$ David K. Smith } \\
\hline Title: & $\begin{array}{ll}\text { Position: } & \begin{array}{l}\text { Nuclear and Radiological Attribution Program } \\
\text { Leader }\end{array}\end{array}$ \\
\hline$(925) 423-5793$ & $(925) 423-5793$ \\
\hline \multicolumn{2}{|l|}{ E-mail: $\quad$ Smith24@1lnl.gov } \\
\hline \multicolumn{2}{|l|}{ Project Coordinator: $\quad$ Michael J. Kristo } \\
\hline Title: & Position: \\
\hline$(925) 422-7714$ & Fax: $\quad(025) 422-3160$ \\
\hline kristo2@1lnl.gov & \\
\hline
\end{tabular}

\section{Project Duration}

18 months

\section{Project Location and Equipment}

\begin{tabular}{|l|l|}
\hline \multicolumn{1}{|c|}{ Institution } & \multicolumn{1}{c|}{ Location, Facilities and Equipment } \\
\hline $\begin{array}{l}\text { Leading Institution } \\
\text { RFNC VNIITF }\end{array}$ & $\begin{array}{l}\text { The project will be implemented at RFNC-VNIITF (456770, Russia, Snezhinsk, } \\
\text { Chelyabinsk region, RFNC-VNIITF, P.O.Box 245, office \# 414 of Administrative } \\
\text { building No.2.) }\end{array}$ \\
\hline Participant Institution 1 & There are no other participant institutions \\
\hline
\end{tabular}

\section{Total Project Effort}

\begin{tabular}{|l|c|}
\hline Total number of participants & 38 \\
\hline Number of weapon scientists and engineers & 15 \\
\hline Total project effort (person*days) & 1744 \\
\hline Total project effort of weapon scientists and engineers (person*days) & 1189 \\
\hline
\end{tabular}

\section{Financial Information}

\subsection{Estimated Project Costs}

\begin{tabular}{|c|c|}
\hline Estimated total cost of the project (US \$) & 120000 \\
\hline \multicolumn{2}{|l|}{ Including: } \\
\hline Payments to Individual Participants & 73500 \\
\hline Equipment & 21500 \\
\hline Materials & 1000 \\
\hline Other Direct Costs & 9000 \\
\hline Travel & 9000 \\
\hline Overhead & 6000 \\
\hline
\end{tabular}

\subsection{Funding Sources}

Estimated total cost of the project (US \$)

Financial Sources:

Requested from the ISTC

Other financial source 1 : Partner - LLNL

Non-Financial Sources:

Non-financial source 1 


\section{Summary of the project}

Within 2004... 2008 RFNC- VNIITF has performed the direct contract with LLNL №B513798 «Identification of the characteristics of the research reactor fuel» and partner ISTC project №3596 «Development of the approaches to the database creation on the research reactor fuel in the interests of the illegal nuclear material traffic counteraction » in the interests of the illegal nuclear materials traffic counteraction. The proposed partner project continues that work.

When performing the ISTC project №3596 we have developed the database status and structure, proposed it software and hardware, estimated the required information content, as a first approximation, proposed conditions for loading of the database with information, it location, the membership of the operating personnel, methods for information protection, access to the database and handling with sensitive information. We will use these studies within the present project. The consultations with U.S. partners show that the part of information may be «sensitive», and therefore the exchange of that information need to be postponed, but the place in the database will be provided.

The fuel of the active zones of the research reactors may be of great interest for the persons pursuing unlawful goals, because it is made predominantly from high-enriched uranium. When detecting «unknown» nuclear material, it is necessary to identify it, to determine the place of it stealing, production and possible using. During the identification it is necessary to determine many parameters and to correlate them with available information on the characteristics of the reactor fuel elements. Therefore the information database containing design, technological and material testing characteristics of domestic and foreign nuclear reactors may be very useful instrument both for research and design purposes and for enforcement of law.

The similar activities are performed during last years in cooperation with ROSATOM and Joint Research Centre of European Committee (JRC), particularly, in VNIINM (Moscow) and in the Institute of Transuranuim Elements (ITE, Karlsrue, Germany). They create the database on the characteristics of the power reactors. Creation of the database on the fuel of the research reactors allows us to obtain full and representative picture on the fuel of the nuclear reactors of different purpose.

Overall goal of the project- to develop the plan for the creation of the joint database on the characteristics of the research reactors, including the identifying characteristics of their fuel, to create the database structure and user interface, to develop the criteria for selecting research reactors, information on which can be included into the database and it initial loading with open information on the U.S. and R.F. research reactors. Information will be loaded into the database simultaneously, step-by-step, to ensure an equal amount of information from each country in the database.

Within the present project VNIITF and LLNL will develop the plan for the creation of the joint database on the characteristics of the research reactors (including their fuel), will create the database structure and will load it with open information on the U.S. and R.F. research reactors of the first generation. The database will include the following fuel parameters for each U.S. and R.F. (former Soviet) reactor:

- Mechanical design of fuel elements;

- Chemical composition of the fuel;

- Elemental composition of the fuel, including fuel additives and trace impurities (contamination);

- Isotopic composition of the major element $(\mathrm{U}$ or $\mathrm{Pu})$;

- Any other unique design features of the fuel element;

The plan will meet the following requirements:

1. Identification of the selection criteria for research reactors and the identification of which Russian (former Soviet) and American reactors can be included in the database and which not. For those reactors that cannot be included in the database, it is necessary to provide an explanation, for example, the government will not approve the release of the information, the information includes classified or proprietary information, the information does not exist or is known with large errors, etc.;

2. For those reactors that can be included in the database, identification of any fuel attributes that cannot be included in the database;

3. Description of the procedures necessary for obtaining the above information and including it in the database, including the list of any approvals, agreements and statements necessary for information obtaining and loading it into the database;

As a result of this project, the plan for the creation of the database will be developed and issued, the conditions and restrictions on its information content will be specified, and the conclusion about it applicability to the interests of both illegal trafficking of nuclear materials and reactor research and design will be clearly stated. According to the results of the project, the decision can be made about the continuation of these activities and extension of the content of the database with information about additional reactors. 


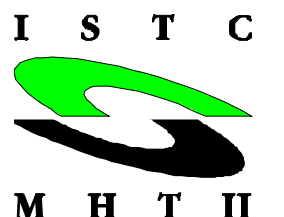

PROJECT PROPOSAL

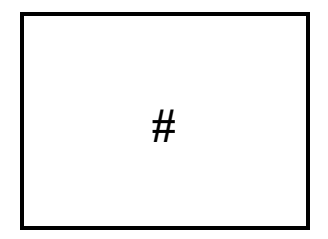

\section{Detailed Project Information}

\section{Introduction and Overview}

Currently, the importance of the problems for identifying nuclear materials, radioactive substances and radioactive wastes taken from illegal traffic grows Within 2004...2008 RFNC- VNIITF has performed the direct contract with LLNL №B513798 «Identification of the characteristics of the research reactor fuel» and partner ISTC project №3596 «Development of the approaches to the database creation on the research reactor fuel in the interests of the illegal nuclear material traffic counteraction $»$ in the interests of the illegal nuclear materials traffic counteraction. The proposed partner project is a continuation of those studies.

When performing the ISTC project №3596 we have developed the database status and structure, proposed it software and hardware, estimated the required information content, as a first approximation, proposed conditions for loading of the database with information, it location, the membership of the operating personnel, methods for information protection, access to the database and handling with sensitive information. We will use these studies within the present project. The consultations with U.S. partners show that the part of information may be «sensitive» and therefore the exchange of that information need to be postponed, but the place in the database will be provided.

At the present times there are about 500 operating and stopped research reactors. For the most part, they are concentrated in U.S. and former USSR. The fuel of active zones of the research reactors may be of great interest for the persons pursuing unlawful goals, because it is made predominantly from high-enriched uranium. When detecting «unknown» nuclear material, it is necessary to identify it, to determine the place of it stealing, production and possible using. During the identification it is necessary to determine many parameters and to correlate them with available information on the characteristics of the reactor fuel elements. Therefore the information database containing design, technological and material testing characteristics of domestic and foreign nuclear reactors may be very useful instrument both for research and design purposes and for enforcement of law.

First research reactors in USSR have been created in the fifties, in the period of active development of nuclear technologies - F1 (1946), TVR (1949), RFT (1952), IR (1952), AM (1954), BR-1 (1954), BR-2 (1956), VVR-2 (1955), IRT (1957), IR-50 (1961) and at the present time the most part of them is either removed or updated essentially both in design and fuel term. Some information on these reactors is in the books, papers in scientific journals, reports at the conferences (for example, international conferences of 1955... 1958 in Geneva), in Internet.

Currently, there are more than 10 types of TVS for the research reactors. They can be distinguished by composition, number of elements and type of assembly. Different fuel has been produced for the MP, IRT, VVP-M, VVP-K IVV-2M, IR-8, BR-10 IBR-30 research reactors of NIIAR. The fuel elements and assemblies can be distinguished by their sizes and by uranium loading. The fuel composition also differs considerably.

The term «research reactor» is not single valued. Within the project we consider it rather broadly and we refer to the research reactors also the critical bench (or reactors with zero power), research reactors with large power, at which the design of different fuel elements is developed, pulsed reactors, training reactors and prototype reactors of the transportable nuclear energy facilities. Many research reactors have a large amount of spent fuel assemblies that are stored in the cooling ponds. We consider that the database must contain information about all research reactors in the world, maybe excepting some specific reactors.

Overall goal of the project- development of the plan for the creation of the joint database on the characteristics of the research reactors, including the identifying characteristics of their fuel, creation of the database structure and user interface, development of the criteria for selecting research reactors information on which can be included into the database and it initial loading with open information on the U.S. and R.F. research reactors. Information will be loaded into the database simultaneously, step-by-step, to ensure an equal amount of information from each country in the database. The information intended for the loading into the database will pass an expertise in the prescribed order.

The similar activities are performed during last years in cooperation with ROSATOM and Joint Research Centre of European Committee (JRC), particularly, in VNIINM (Moscow) and in the Institute of Transuranium Elements (ITE, Karlsrue, Germany). They create the database on the characteristics of the power reactors. Creation of 
the database on the fuel of the research reactors allows us to obtain full and representative picture on the fuel of the nuclear reactors of different purpose.

Within the present project VNIITF and LLNL will develop the plan for the creation of the joint database on the characteristics of the research reactors, including the fuel characteristics, will create the database structure and will load it with open information on the U.S. and R.F. research reactors of the first generation. Database will include the following parameters for each U.S. and R.F. (former Soviet) reactor:

- Mechanical design of fuel elements;

- Chemical composition of the fuel;

- Elemental composition of the fuel, including fuel additives and trace impurities(contamination);

- Isotopic composition of the major element $(\mathrm{U}$ or $\mathrm{Pu})$;

- Any other unique design features of the fuel element;

The plan will meet the following requirements:

1. Identification of the selection criteria for research reactors and the identification of which Russian (former Soviet) and American reactors can be included in the database and which not. For those reactors that cannot be included in the database, it is necessary to provide an explanation, for example, the government will not approve the release of the information, the information includes classified or proprietary information, the information does not exist or is known with large errors, etc.;

2. For those reactors that can be included in the database, identification of any fuel attributes that cannot be included in the database;

3. Description of the procedures necessary for obtaining the above information and including it in the database, including the list of any approvals, agreements and statements necessary for information obtaining and loading it into the database;

The work is planned to be accomplished in two stages (2009-2010):

First stage (2009):

1. Analysis of all R.F. and U.S. research reactors and the selection of those reactors, information about which can be included into the database.

2. Development of the plan for including information into the joint database on the characteristics of the research reactors.

3. Creation of the database structure on the basis of the Access code.

4. Analysis of the unique features of the fuel element identification for several former Soviet reactors, preparation and issue of the papers.

After the first stage of work the second one is being corrected financial structure of project without changing the scope of funding - the necessity and list of equipment, business trips and partner meetings are being planed. By the results of the first stage we will take a decision about the going to the second stage (2009...2010):

1. Selection of the basic software, implementation of the software for database creation, creation of the database structure and interface, and the development of the procedures for fuel identification and information analysis.

2. The step-by-step loading of the database with information on the characteristics of U.S. and R.F.(former Soviet) research reactors according to the developed plan.

\section{Expected Results and Their Application}

As a result of this project, the plan for the creation and information loading of the joint database on the characteristics of the U.S. and R.F. research reactors will be developed and issued, the database structure will be created and initially loaded with information. Currently, only senior citizens possess all the necessary information. In the coming years they will finish their careers. Therefore it is necessary to record their knowledge and experience for future generations. The information on the results of the experiments at the reactors is less or more concentrated, but the information on the reactors is contained in many conference reports and papers. Source documents have long became the bibliographic rarities, so within the project their search and their conversion into the computer form should be begun in order to preserve them and to make them available for scientific community.

According to the obtained result, the decision can be taken about continuation of the activities and more full content of the database with the information on modern reactors.

\subsection{Sustainability Implementation Plan}

\subsubsection{Results to be promoted}

The project results directed to increasing safety and non-proliferation of nuclear materials and are not for commercial goals. 


\subsubsection{Uniqueness of results}

The work in this direction is being conducted jointly by Rosatom and the Joined Research Center of the European Commission (JRC), in particular by VNIINM (Moscow, Russia) and the Institute of Transuranuim Elements (ITE, Karlsrue, Germany). The project results will add to these works.

\subsubsection{Demand for results}

The problems of NM non-proliferation and identification have been given much attention in recent years, the project results will be demanded.

\subsubsection{Expected income}

There will be no explicit profit from the project implementation. The expected income may be presented as the increase of safety in the world as a result of NM non-proliferation.

\subsubsection{IPR situation}

The intellectual property rights will be owned by the developers of concrete technical solutions.

\subsubsection{Additional developments}

The works on problems of non-proliferation and identification are being conducted more extensively than it is reflected in the project.

\subsubsection{Plan of implementation}

As the project is implemented and the technical solutions supporting NM non-proliferation and identification are developed, they will be patented and applied to practical works with SNF.

\subsubsection{Additional licenses or permits} not required.

The participating enterprises have all necessary licenses. At the present stage, additional licenses or permits are

\subsubsection{Business network}

The business network of contacts between US and Russian weapons laboratories is being promoted, in particular in the framework of the present project.

\section{Meeting ISTC Goals and Objectives}

The project will give possibility for weapon experts to change their activities, it will help to solve national and international problems of the illegal nuclear materials traffic counteraction and non-proliferation problem.

The result of the work will be callable in any country possessing research reactors and interested in the increase of their operating safety.

\section{Scope of Activities}

\section{Task 1}

\begin{tabular}{|c|c|}
\hline Task & $\underline{\mathbf{P a}}$ \\
\hline $\begin{array}{l}\text { selection of those react } \\
\text { ase. }\end{array}$ & State \\
\hline \multicolumn{2}{|l|}{ Description of deliverables } \\
\hline \multicolumn{2}{|c|}{$\begin{array}{l}\text { Report on the substantiation of the reactor selection criteria, with the analysis of the available IAEA database } \\
\text { on the research reactors, with the analysis of the publications on the R.F. (USSR) and U.S. research reactors } \\
\text { Development of the criteria for selecting reactors for inclusion into the database. }\end{array}$} \\
\hline
\end{tabular}


Task 2

\begin{tabular}{|c|l|}
\hline \multicolumn{1}{|c|}{ Task description and main milestones } & Participating Institutions \\
\hline $\begin{array}{l}\text { Development of the plan for the loading of the joint database with information on } \\
\text { the research reactor characteristics. }\end{array}$ & $\begin{array}{l}\text { RFNC VNIITF, } \\
\text { Statecorporation Rosatom }\end{array}$ \\
\hline \multicolumn{2}{|c|}{ Description of deliverables } \\
\hline 1 & $\begin{array}{l}\text { The plan for creation of the database with description of the procedures necessary for obtaining the } \\
\text { information and including it into the database. The plan, except criteria for selection, will include the list of } \\
\text { any approvals, agreements and statements, necessary for obtaining the information and including it into the } \\
\text { database. }\end{array}$ \\
\hline
\end{tabular}

Task 3

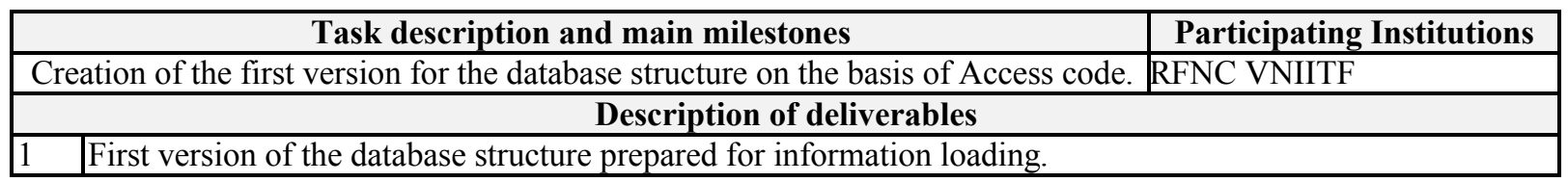

Task 4

\begin{tabular}{|c|c|}
\hline Task description and main milestones & Participating Institutions \\
\hline $\begin{array}{l}\text { Analysis of the unique features for identifying fuel elements of several former } \\
\text { Soviet reactors, preparation and publication of the papers. }\end{array}$ & $\begin{array}{l}\text { RFNC VNIITF, } \\
\text { Statecorporation Rosatom }\end{array}$ \\
\hline \multicolumn{2}{|l|}{ Description of deliverables } \\
\hline Publication of several papers according to the results of the analysis. & \\
\hline
\end{tabular}

Task 5

\begin{tabular}{|c|c|}
\hline Task description and main milestones & Participating Institutions \\
\hline $\begin{array}{l}\text { The joint workshop with the partners for discussing the obtained results and } \\
\text { taking decision about the second stage of work. }\end{array}$ & $\begin{array}{l}\text { RFNC VNIITF, } \\
\text { Statecorporation Rosatom }\end{array}$ \\
\hline \multicolumn{2}{|l|}{ Description of deliverables } \\
\hline Joint workshop & \\
\hline
\end{tabular}

Task 6

Task description and main milestones

Participating Institutions

Selection of the main software, implementation of the database software, creation RFNC VNIITF

of the database structure and user interface, development of the procedures for

information identification and analysis.

Description of deliverables

1 User manual for database generation, identification procedures and information analysis.

Task 7

\begin{tabular}{|l|l|}
\hline \multicolumn{1}{|c|}{ Task description and main milestones } & Participating Institutions \\
\hline $\begin{array}{l}\text { The step-by-step loading of the database with information on the characteristics } \\
\text { of R.F. (former Soviet) and U.S. research reactors. }\end{array}$ & DFC VNIITF \\
\hline \multicolumn{2}{|c|}{ Description of deliverables } \\
\hline 1 & Report on the results of the experimental database operation. \\
\hline
\end{tabular}

\section{Role of Foreign Collaborators/Partners}

1. Discussion and agreement of the conditions for the creation of the joint database on the characteristics of the research reactors, selection criteria, software selection.

2. Selection and approval of R.F. and U.S. reactors for including into the database at the first and second stages of the work.

3. Preparation of the information on the characteristics of the U.S. research reactors for their including into the joint database.

4. Conduct of the joint workshop for discussing the results of the first year- to agree the list of R.F. and U.S. research reactors, to choose the selection criteria, information format and basic software. 


\section{Technical Approach and Methodology}

When solving the task №1 we will determine the sensitivity of this subject on the research reactors, the sensitivity of the database on the fuel characteristics of the research reactors, data field in the database that can be referred to the sensitive information. Analyzing the characteristics of the research reactors included into IAEA, we will direct the main attention on the detection of the design and fuel features for the most available world reactors that will be entered into the developed structure of the database.

When solving the task №2 the emphasis will be directed on the equal loading of the database with information on the R.F. and U.S. research reactors, on the peculiarities of the information export-import, on information protection and security, on the choice of the place for R.F. and U.S. database parts, on implementation of the access to it, etc.

When solving the tasks №3 and №6 the emphasis will be directed on the search of the compromise between the following (sometimes contradictory) conditions - compliance with technical requirements, ensuring the database efficiency, information protection and safety, exclusion of the unauthorized access to the database, the possibility for the search of necessary information, accessibility of the database and interface for most experts-physicists.

When solving the task №5 the main attention will be directed on the analysis of the obtained results of the first stage and on the substantiation of further continuation.

When solving the tasks №4 and №7 we will analyze the open sources of the information, make it annotations, prepare required illustrations (figures, drafts, photos, films) in corresponding format, develop corresponding e-forms and paper forms for initial filling and input into the database corresponding objects. 
7. Technical Schedule

\begin{tabular}{|c|c|c|c|c|c|c|c|}
\hline & Quarter 1 & Quarter 2 & Quarter 3 & Quarter 4 & Quarter 5 & Quarter 6 & $\begin{array}{l}\text { Person* } \\
\text { days }\end{array}$ \\
\hline Task 1 & \multicolumn{2}{|c|}{$\begin{array}{c}\text { Analysis of all R.F. and U.S. research } \\
\text { reactors and the selection of those reactors, } \\
\text { information about which can be included } \\
\text { in the database. }\end{array}$} & & & & & \\
\hline Person*days & \multirow{2}{*}{\multicolumn{3}{|c|}{\begin{tabular}{|c|c|c|}
$\mathbf{1 6 5}$ & $\mathbf{8 0}$ & $\begin{array}{c}\text { Development of the plan for including information into the joint database on the } \\
\text { characteristics of the research reactors. }\end{array}$ \\
\end{tabular}}} & & & & 245 \\
\hline Task 2 & & & & & & & \\
\hline Person*days & 55 & \begin{tabular}{|r|}
$\mathbf{8 0}$ \\
\end{tabular} & $\mathbf{7 0}$ & & & & 205 \\
\hline Task 3 & & \multicolumn{2}{|c|}{$\begin{array}{l}\begin{array}{l}\text { Creation of the first version of the database structure on the basis of } \\
\text { Access code }\end{array} \\
\end{array}$} & & & & \\
\hline Person*days & \multirow{2}{*}{\multicolumn{3}{|c|}{\begin{tabular}{l|c|c|} 
& $\mathbf{4 0}$ & $\mathbf{4 0}$ \\
Analysis of the unique features for identifying fuel elements for several former \\
Soviet reactors, preparation and publication of the papers.
\end{tabular}}} & & & & 80 \\
\hline Task 4 & & & & & & & \\
\hline Person*days & 70 & 40 & 20 & & & & 130 \\
\hline Person*days & & 15 & 55 & & & & 70 \\
\hline Task 6 & & \multicolumn{5}{|c|}{$\begin{array}{l}\text { Selection of the basic software, creation of the software, creation of the database structure and user interface, } \\
\text { development of the procedures for information identification and analysis }\end{array}$} & \\
\hline Person*days & & 35 & 40 & 140 & \begin{tabular}{|l|}
60 \\
\end{tabular} & 64 & 339 \\
\hline Task 7 & & & \multicolumn{4}{|c|}{$\begin{array}{l}\text { Step-by-step loading of the database with information o the characteristics of } \\
\text { R.F.(former Soviet) and U.S. research reactors. }\end{array}$} & \\
\hline Person*days & & & 65 & 150 & 230 & 230 & 675 \\
\hline TOTAL & 290 & 290 & 290 & 290 & 290 & 294 & 1744 \\
\hline
\end{tabular}




\subsection{Managerial responsibilities}

The structure of project is shown on picture

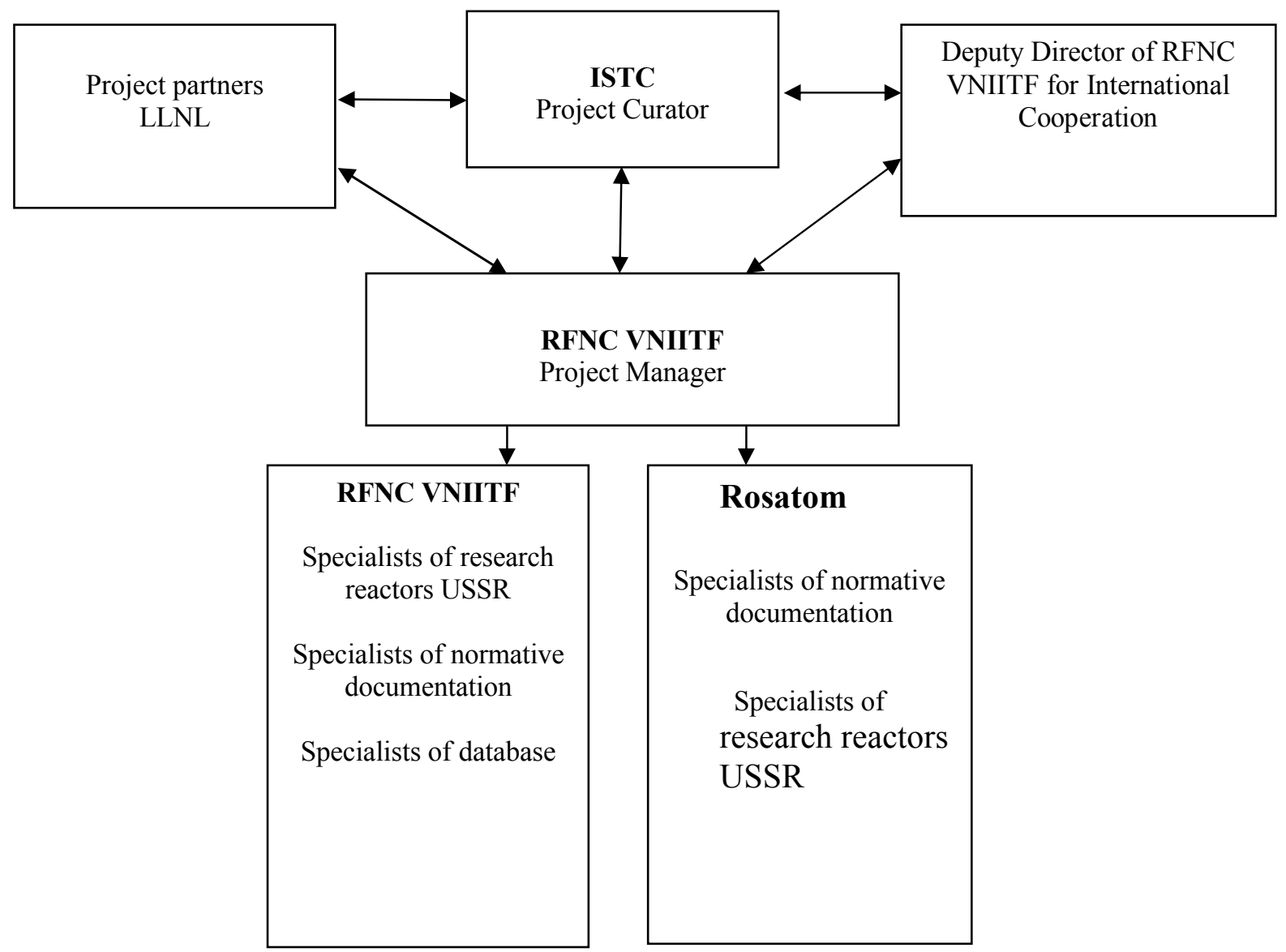




\section{Financial Information}

\subsection{Estimated Project Costs (US \$)}

\begin{tabular}{|l|c|}
\hline Estimated total cost of the project & 120000 \\
\hline Leading Institution & 120000 \\
\hline
\end{tabular}

9.1.1. Payments to Individual Participants (US \$)

\begin{tabular}{|c|c|c|c|c|}
\hline Institution & Category I & Category II & $\begin{array}{c}\text { Supporting } \\
\text { personnel }\end{array}$ & Total \\
\hline Leading Institution & 55725 & 9975 & 7800 & 73500 \\
\hline
\end{tabular}

9.1.2. Equipment

\begin{tabular}{|l|l|c|}
\hline \multicolumn{1}{|c|}{ Institution } & \multicolumn{1}{|c|}{ Equipment description } & Cost (US \$) \\
\hline Leading Institution & Personal computer/server (4) & 8800 \\
& Projector & 4900 \\
& Notebook (2) & 5000 \\
& Handheld computer & 1100 \\
& Digital camera (2) & 1200 \\
& Printer & 500 \\
\hline
\end{tabular}

9.1.3. Materials

\begin{tabular}{|l|l|c|}
\hline \multicolumn{1}{|c|}{ Institution } & \multicolumn{1}{|c|}{ Materials description } & Cost (US \$) \\
\hline Leading Institution & Paper for printers A4 & 500 \\
& Stationery & 500 \\
\hline
\end{tabular}

\subsubsection{Other Direct Costs}

\begin{tabular}{|c|c|c|}
\hline Institution & Direct costs description & Cost (US \$) \\
\hline Leading Institution & $\begin{array}{l}\text { Conduct of the joint workshops } \\
\text { Communication service } \\
\text { Et alia }\end{array}$ & $\begin{array}{l}5000 \\
1500 \\
2500\end{array}$ \\
\hline & Subtotal: & 9000 \\
\hline
\end{tabular}

9.1.5. Travel costs (US \$)

\begin{tabular}{|c|c|c|c|}
\hline Institution & CIS travel & International travel & Total \\
\hline Leading Institution & 9000 & 0 & 9000 \\
\hline Subtotals: & 9000 & 0 & 9000 \\
\hline
\end{tabular}

9.1.6. Overhead (US \$)

\begin{tabular}{|c|c|c|}
\hline Institution & & Amount \\
\hline Leading Institution & 6000 & 6000 \\
\hline & 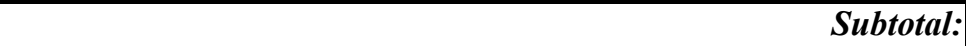 & 6000 \\
\hline
\end{tabular}




\subsection{Funding Sources}

9.2.1. Financial Sources

\begin{tabular}{|l|c|c|}
\hline \multicolumn{1}{|c|}{ Financial Source } & $\begin{array}{c}\text { Written } \\
\text { confirmation } \\
\text { (Y/N) }\end{array}$ & $\begin{array}{c}\text { Amount } \\
\text { (US \$) }\end{array}$ \\
\hline Requested from the ISTC & & 0 \\
\hline Other financial source 1 Partner - LLNL & Y & 120000 \\
\hline
\end{tabular}

\subsubsection{Non-Financial Sources}

\begin{tabular}{|l|c|c|c|}
\hline Source & Short description of contribution & $\begin{array}{c}\text { Written } \\
\text { confirmation } \\
\text { (Y/N) }\end{array}$ & $\begin{array}{c}\text { Estimated } \\
\text { amount } \\
\text { (US \$) }\end{array}$ \\
\hline no & no & 0 \\
\hline
\end{tabular}

\subsubsection{Submitted for Funding to Program Beside the ISTC}

No proposals on the topic of the project are submitted for funding to program beside the ISTC.

\section{Intellectual Property Statement}

The rights for intellectual property that are generated during the course of the project will be regulated by the laws of the Russian Federation and by the procedures, which have been developed by the ISTC.

The general conditions on Intellectual Property Rights as described in the Model Project Agreement will be observed.

\section{Monitoring and Auditing Statement}

In accordance with Article VIII of the ISTC Agreement, project recipients will give to the Center and to each Party which wholly or partly finances a project the right of access to carry out on-site monitoring and audit of all activities of the project. Project agreements will specify the portions of facilities, equipment, documentation, information, data systems, materials, supplies, personnel, and services which will concern the project and therefore will be made accessible for monitoring and audit. Project recipients shall have the right to protect those portions of facilities that are not related to the project.

\section{Supporting Information}

None 